\title{
Analysis of sports and recreation activities development in the Republic of Sakha (Yakutia)
}

\author{
Taras Artemenko ${ }^{1}$, Elena Artemenko ${ }^{1 *}$, Sayana Nikoforova ${ }^{2}$ \\ ${ }^{1}$ Churapchinsky State Institute of Physical Culture and Sports, 678671, Churapcha, Republic of Sakha (Yakutia), Russia \\ ${ }^{2}$ Department of Physical Culture and Mass Sports, 677000, Yakutsk, Republic of Sakha (Yakutia), Russia
}

\begin{abstract}
The article is devoted to the current project of physical culture, sports and health activities development in the Republic of Sakha (Yakutia). The article presents the main trends in the development of physical culture, sports and health activities in the country and in the conditions of living in the Republic of Sakha (Yakutia). The authors show the dynamics of growth in the number of regularly engaged in physical culture and sports, indicators of children's and youth sports development. The authors created an actual register of physical culture and sports clubs in the Republic of Sakha (Yakutia). The majority of sports and health clubs and associations operating on the territory of the Republic do not have state registration and founders' documents. In municipalities, there is a shortage of qualified specialistsorganizers of physical culture movement and the need for awareness-raising and advisory work among the mature and elderly population. The climatic and geographical features of the Northern region, the duration of the cold season, and the lack of appropriate sports infrastructure cause to build a system of measures for wider involvement of the Republic of Sakha (Yakutia) population in systematic physical exercises through the organization of physical culture and sports clubs on the ground.
\end{abstract}

\section{Introduction}

With the development of society, physical activity and sports are increasingly penetrating into all areas of people's lives, becoming an increasingly important and integral part of the world civilization. Currently, millions of people in all countries of the world lead a healthy lifestyle. It includes physical activity and wellness practices, participation in sports competitions. The successful development of physical culture and mass sports is important for strengthening the health of citizens and improving their quality of life. It is one of the key factors that ensure sustainable socioeconomic development of the state [1].

The most effective organizational form for the mass sports development and increasing its social significance is a sports club at the place of residence. Sports facilities for professionals and amateurs. Sports clubs for children and local playgrounds should make a healthy lifestyle interesting and accessible, as well as attract the population to regular physical education and sports [2].

According to Federal Law No. 329-FZ of December 4, 2007 "on physical culture and sports in the Russian Federation", sports clubs can be created by legal entities and individuals in the form of physical culture and sports clubs at the place of residence, work, school sports clubs, student sports clubs, professional sports clubs and others [3].

On November 22, 2019, President of the Russian Federation Vladimir Putin approved a list of instructions following a meeting of the presidential Council for the development of physical culture and sports. Thus, by 2024 , school and student sports clubs should be established in general education organizations, professional educational organizations and higher education organizations, as well as the participation of such clubs in sports competitions held by school and student sports leagues [4].

The head of state also instructed to develop the subprogram "sports in rural areas" of the state program "Development of physical culture and sports" by April 20, 2020 and establish standards and norms for providing the population with sports infrastructure facilities [5].

The President of the Russian Federation recommended the regional authorities, to implement the "Active longevity" program in all regions, encourage both the creation of sports clubs at the place of residence and work of citizens, and participation in them. It is necessary to take measures to expand the use of public-private partnership agreements and concession agreements in the construction, reconstruction and operation of sports facilities [4].

\section{Materials and methods}

\footnotetext{
*Corresponding author: ewa_12@ukr.net
} 
The sphere of sports and physical culture remains one of the priorities of social policy for the Republic of Sakha (Yakutia). The fundamental law in the development of physical culture and sports in the Republic is the Law of 18.06. 2009 696-Z No. 3 27-IV "on physical culture and sports in the Republic of Sakha (Yakutia)" [6].

The Concept of children's and youth sports development in the Republic of Sakha (Yakutia) for 2014-2021 takes place (Order of The head of the RS (Yakutia) from 13.05.2014 No. 420-RG). As a result of the Concept implementation, it is expected to create sports clubs in each educational organization of the Republic [7].

In accordance with the Strategy of physical culture and sports development in the Russian Federation for the period up to 2020, the government of the Republic of Sakha (Yakutia) in the sphere of physical culture and sports is directed to the use of the industry in the formation of healthy lifestyle of the population, creation of conditions for development of physical culture and sports, attracting different segments of the population, including children, adolescents and young people to the regular practice of mass physical culture and sports, their recovery, improve physical development and crime prevention. In this regard, the decree of the Head of the Republic of Sakha (Yakutia) adopted a long-term state program "Development of physical culture and sports in the Republic of Sakha (Yakutia) for 2018-2022" [7].

It is planned to implement measures to stimulate the activities of clubs in the place of residence. The List of measures of the Republic of Sakha (Yakutia) to create conditions for physical culture and sports in General education organizations located in rural areas was approved (decree of the government of the Republic of Sakha(Yakutia) No. 73-R of 26.01. 2017).

Government Resolution of the Republic of Sakha (Yakutia) No. 524 of 11.12.2009 approved the Strategy for the development of physical culture and sports in the Republic of Sakha (Yakutia) for the period up to 2020. By the end of 2020, a Strategy for the development of physical culture and sports in the Russian Federation until 2030 will be developed and adopted [5].

There are regional sports federations that are members of all-Russian sports federations, or a structural division (regional branch) of the all-Russian Sports Federation. They received state accreditation. The goals of regional sports federations are the development of one or more sports on the territory of the Russian Federation subjects, their promotion, organization, holding of sports events and training of athletes-members of the Russian Federation subject sports teams [8].

The register of accredited sports federations of the Republic of Sakha (Yakutia) (for sports included in the program of the Olympic Games, Olympic winter games, sports for disabled people, sports not included in the program of the Olympic Games and Olympic winter games) includes 38 public organizations.

\section{Results and discussion}

The development of sports clubs and federations requires constant improvement of financial support measures, optimization of the physical education system in schools, universities, and colleges, development of the material and technical base of sports schools and decent pay for the work of the coaching staff.

Currently, the number of Yakut people aged $3-79$ years who systematically engage in physical culture and sports in the total population reached $38.7 \%$ in 2019. the share of citizens who systematically engage in physical culture and sports in rural areas is $24 \%$. The share of citizens who systematically engaged in adaptive physical culture and sports is $17 \%$. The level of the population provision with sports facilities, based on the one-time capacity of sports facilities, reached $38.7 \%$ [7].

Lack of time, poor condition, lack of money, willpower, remoteness or lack of sports facilities are often the main obstacles on the way to sports.

Over the past five years, the number of those who regularly attend sections and gyms increased by almost $11 \%$. However, today the involvement of the working-age population in systematic physical education is not high.

In order to involve various categories and groups of the population in systematic physical culture and sports, the list of sports events included in the Unified calendar of interregional, all - Russian and international physical culture events and sports events (hereinafter as UCI) is expanded annually.

In 2019, more than 570 events were held in the Republic within the framework of the UCI, which is $17.5 \%$ more than in 2014. There are 1,754 sports facilities in the Republic, and more than 500 mass physical culture and sports events are held annually in the Republic. These events provide an opportunity to attract only more than 300 thousand people to competitive activities. The demand for the development of mass physical culture and sports work in the field remains an urgent problem.

Harsh climatic conditions, the remoteness of the Republic of Sakha (Yakutia) from recreation centers and Spa treatment, constantly rising prices for medicines-all these factors strongly require additional measures to increase the physical activity of the Republic's residents, especially children, adolescents, boys and girls.

Physical culture and sports are the key means of promoting the values of a healthy lifestyle, successful socioeconomic development of the country and improvement the overall quality of the population life.

One of the state socio-economic policy priorities of the Republic of Sakha (Yakutia) is the development of physical culture and sports. It is reflected in the Charter of the Republic and the charters of municipalities.

The following levels of the physical culture and sports system management in the Republic of Sakha (Yakutia) can be distinguished:

- Republican system; 
- municipal system;

- individual institution;

- training and educational processes.

Today the priority policy of the Republic of Sakha (Yakutia) government in the social sphere is to promote physical culture and sports in the education of a fully developed and spiritually rich person. The strategy for the development of physical culture and sports in Republic of Sakha (Yakutia) until 2020 indicates ways to improve state policy aimed at increasing the role of physical culture and sports in the formation of a healthy lifestyle of the population.

According to Table 1, the results of mass physical culture and sports work carried out in the Republic of Sakha (Yakutia) allowed to increase the share of systematically engaged in physical culture from the total population by $11.2 \%$ in 2019, compared to 2014. In the Republic of Sakha (Yakutia) 520 sports, recreation and mass sports events were held in 2019.

Table 1. Development of mass sports in the Republic of Sakha ( Yakutia)

\begin{tabular}{|c|c|c|c|c|c|c|c|}
\hline \multirow[t]{2}{*}{ Name of the target indicator } & Unit & \multicolumn{6}{|c|}{ Accounting period } \\
\hline & $\%$ & 2014 & 2015 & 2016 & 2017 & 2018 & 2019 \\
\hline $\begin{array}{l}\text { Percentage of citizens who regularly engage } \\
\text { in physical culture and sports in the total } \\
\text { population }\end{array}$ & & 29,4 & 30,0 & 32,0 & 34,0 & 36,0 & 38,0 \\
\hline $\begin{array}{l}\text { Percentage of citizens who regularly engage } \\
\text { in physical culture and sports in rural areas in } \\
\text { the total population }\end{array}$ & $\%$ & 10,6 & 11,2 & 11,8 & 12,5 & 13,2 & 13,8 \\
\hline $\begin{array}{l}\text { Percentage of citizens who regularly engage } \\
\text { in adaptive physical culture and sports }\end{array}$ & $\%$ & 6,6 & 7,8 & 8,9 & 12,0 & 15,0 & 17,0 \\
\hline $\begin{array}{l}\text { Number of physical culture and health, sports } \\
\text { and mass events held }\end{array}$ & $\%$ & 450 & 430 & 420 & 435 & 450 & 520 \\
\hline The throughout capacity of sports objects & $\%$ & 27 & 30 & 32 & 34 & 36 & 38 \\
\hline $\begin{array}{l}\text { Indicator: the share of citizens who met the } \\
\text { standards of the TRP in the total population, } \\
\text { participated in the implementation of the } \\
\text { standards of the TRP complex }\end{array}$ & $\%$ & - & 10 & 15 & 20 & 25 & 30 \\
\hline
\end{tabular}

The development dynamics of sports and recreation activities in the Republic of Sakha (Yakutia) indicates an active policy of a healthy lifestyle, expanding the quality and quantity of health services provided to the population, conducting a wide range of sports events, and developing sports infrastructure.

The studying goals and objectives implementation of sports clubs in the school system of the Republic of Sakha (Yakutia) showed that out of 34 municipal districts (uluses) of the Republic, 30 have schools where these clubs are established and operate. Of the 468 municipal General education institutions, 195 schools have sports clubs, which is a percentage of $46.7 \%$.

Most sports and recreation associations and clubs that include the adult working-age population, as well as elderly and older people, do not have state registration or any founders' documents. There is a shortage of qualified specialists-organizers of physical culture, sports and health-improving work with the population at the place of residence and the need for awareness-raising and advisory work. We meet troudles in counting people who regularly engage in sports. People work out three times a week, but they are not registered in statistical reports. There is a need to clarify the category of the population that falls under systematically engaged in physical culture according to the statistical report and to expand the organization of sports clubs [9].

Based on the climatic and geographical features of the living environment, there is a need to determine the most acceptable types of physical exercises and scientific justification of technologies for organizing outdoor activities. They should accent on optimizing the respiratory and cardiovascular systems, including the practice of hardening the body;

In accordance with the Federal law of the Russian Federation "on physical culture and sports in the Russian Federation" and the Law of the Republic of Sakha (Yakutia) "on physical culture and sports in the Republic of Sakha ( Yakutia)" [8], sports clubs are legal entities engaged in training, competitive, physical culture and educational activities and can be created by legal entities and individuals in the form of physical culture and sports clubs at the place of residence, work, school sports clubs, student sports clubs, professional sports clubs and other.

Based on this, sports clubs can be both commercial organizations and non-profit organizations (public associations).

According to the Ministry of education and science of the Republic of Sakha (Yakutia), 115 school sports clubs in various sports were created for the development of sports and a healthy lifestyle among children. In order to support children's sports, classrooms were converted into sports halls, sports equipment and inventory were purchased in 60 general education organizations located in rural areas, open planar sports facilities were equipped, and artificial turf was installed in more than 20 general education organizations.

The all-Russian public organization " Russian student sports Union in the Republic of Sakha (Yakutia)" unites more than 32 thousand students from seven universities and 33 secondary specialized educational institutions. It is 
currently working hard to develop student sports. The most popular sports are: volleyball, basketball, soccer, mini football, table tennis, athletics, cross-country skiing, chess, sambo, fitness aerobics. During the year, various competitions are held between sports clubs of educational institutions.

For the development of amateur and professional sports in the Republic there are more than 200 clubs that are not legally registered or are commercial organizations. Among them, the most relevant are fitness clubs and martial arts clubs. Among non-commercial sports clubs, the most popular are volleyball clubs. There are about 180 clubs in the Republic (of which only 1 club is registered as an NCO), about 60 clubs in mini-football, 5 clubs in rhythmic gymnastics, 10 sports clubs in mixed martial arts, 6 sports clubs in technical sports, 4 sports clubs in nordic walking, and sports clubs in hockey, parachuting, rhythmic gymnastics, billiards, bullet shooting, etc. During the year, competitions are held in the league format in volleyball, basketball, mini-football and hockey.

In municipal districts, the largest number of sports clubs is in Vilyuysky ulus-30 sports clubs, Aldan district-18 sports clubs, Mirninsky district-15 sports clubs and Amginsky ulus - 14 sports clubs. It is worth noting that most of the sports clubs are located in those municipal areas where a good sports infrastructure is developed.

\section{Conclusions}

Physical culture and sport is an integral part of the social sphere. Its development needs the support of non-profit sports organizations through competitions for grants, and creating resource centers for consultation non-profit sports organizations.

There is an obvious necessity of creating a network of sports clubs. They can realize the most effective implementation of the human need for physical improvement and healthy lifestyle. It should have a positive impact on the economic and spiritual development of society.

On December 16, a round table of the State Assembly (Il Tyumen) was held on the topic " The development of club sports in the Republic of Sakha (Yakutia)". At the round table in February 2020 was developed and adopted recommendations of the round table. They contain instructions to the State Assembly (Il Tyumen) of the Sakha Republic (Yakutia), the Government of the Republic of Sakha (Yakutia), heads of municipal areas and city districts of the Republic of Sakha (Yakutia), public organizations of sports of the Republic of Sakha (Yakutia).

The document recommends the Parliament of Yakutia to make changes to the legislation of the Republic of Sakha (Yakutia) in terms of improving the legal regulation of sports societies and sports clubs, including the establishment of their rights and obligations, as well as the approval of standard regulations on sports clubs. Consideration of the preparation and submission of proposals to the State Duma of the Federal Assembly of the Russian Federation regarding amendments to Federal legislation regulating the activities of sports clubs in 2020.

The authors of the article developed a roadmap for improving the development of club sports in the Republic of Sakha (Yakutia) in order to fulfill the order of the Russian Federation President of October 10, 2019, and increase the share of citizens who lead a healthy lifestyle, citizens who regularly engage in physical culture and sports.

\section{References}

1. V.N. Kremneva, History and modernity in the collection: development of physical culture, sports and tourism of Petrozavodsk state University (Petrozavodsk state University, 32-36, 2016)

2. V.V. Korolainen, Modern problems of regulation of the system of physical culture and sports complex of the country and ways of survival of sports clubs in market conditions (Moscow state University of Economics, statistics and Informatics (MESI), 107-112, 2010)

3. On physical culture and sports in the Russian Federation, 329-FZ (2007)

4. Vladimir Putin, Speech at the meeting of the Council for the development of physical culture and sports in the international forum "Russia - a sports power". URL: http://kremlin.ru/events/president/news/53070 (accessed 17.12.2019).

5. Recommendations for creating sports clubs. URL: http://vertigosports.ru/business/experience

6. Law of the Republic of Sakha (Yakutia), 696-Z (2009)

7. S.S. Gulyaeva, Club organization of sports and recreation activities in the Republic of Sakha (Yakutia) (Churapchinsky state Institute of physical culture and sports, 97-99, 2017)

8. A.S. Kuznetsov, Z.M. Kuznetsova, Russian Journal of Physical Education and Sport, 14(4), 5-7 (2019). DOI: 10.14526/20704798-2019-14-4-5-7

9. A.G. Burov, G.S. Krylova, I.N. Antonova, E.G. Mikhalchenko, Theory and practice of physical culture, 9, 36-38 (2016 